\title{
PROLEGOMENA DO STUDIÓW NAD GRAMOTAMI BRZOZOWYMI
}

\section{PROLEGOMENA TO THE STUDY OF BIRCHBARK MANUSCRIPTS}

\begin{abstract}
Abstrakt: W artykule zasygnalizowane zostały podstawowe zagadnienia związane ze studiami nad gramotami brzozowymi. Szerzej przedstawiono problematykę dotyczącą korespondencji rytej w korze brzozy. Autor omawia wzmianki w Kitāb al-Fihrist i w tzw. Zapytaniach Kiryka. Podkreśla, że gramoty są zabytkami piśmiennictwa, ale też materiałem archeologicznym. Zwraca uwagę na złożony charakter procesów odczytania, analizy, interpretacji i tłumaczenia tekstów zapisanych na korze brzozy. Charakteryzuje gramoty jako produkt działalności człowieka, a wyryte na nich znaki jako informacje przekazywane w ramach aktów komunikacji. Porównuje znaczenie zapisów na gramotach i przekazów źródeł narracyjnych, zauważając, że wartość tych pierwszych trudno przecenić. Dostrzega w gramotach przykład materiału źródłowego mogącego być przedmiotem współpracy międzydyscyplinarnej.
\end{abstract}

Słowa kluczowe: Ruś, Nowogród Wielki, gramoty brzozowe, Kitāb al-Fihrist, Zapytania Kiryka, akt komunikacji, współpraca międzydyscyplinarna

\begin{abstract}
The article looks in some detail at the question of letters written on birchbark even as it presents some the basic research issues involving birchbark manuscripts ("gramota") in general, including the first mentions of this form in the written sources in the Kitäb al-Fihrist and the socalled Questions of Kiryk. The author draws attention to the complex nature of the processes of reading, analyzing, interpreting and translating texts written on birchbark, which are literature on one hand, but archaeological sources on the other. Gramota are products of human activity, and the signs engraved on them contain information passed on in an act of communication. The author compares the significance of manuscripts on birchbark with that of narrative sources, noting the inestimable value of the former. Gramotas are to his view a kind of source material well suited to interdisciplinary studies.
\end{abstract}

Keywords: Rus', Great Novgorod, birchbark manuscripts, Kitāb al-Fihrist, The Questions of Kiryk, act of communication, interdisciplinary studies

a Dr Karol Kollinger, Ośrodek Historii Kultury Materialnej Średniowiecza i Czasów Nowożytnych, Instytut Archeologii i Etnologii PAN, al. Solidarności 105, 00-140 Warszawa, karolkollinger@gmail.com, ORCID iD: https://orcid.org/0000-0002-4362-8338. 
Znajdowane $\mathrm{w}$ trakcie wykopalisk archeologicznych i podczas prac budowlanych, nie tylko w Nowogrodzie Wielkim, zwitki kory brzozowej ${ }^{1}$, a dokładnie białej warstwy, zapisane na jej wewnętrznej, bardziej miękkiej, stronie, niekiedy na zewnętrznej, rzadko natomiast na obu, zajęły ważne miejsce w badaniach nad średniowieczną Rusią ${ }^{2}$. Uczeni nazwali je od staroruskiego terminu грамота oznaczającego m.in. „dokument” oraz „list” (Tihomirov 1953, s. 15; Poppe 1954, s. 370; por. Lihačëv 1954, s. 326; Zaliznâk 2004, s. 17; Dekker 2018, s. 7), co z kolei pochodzi od greckiego słowa $\gamma \rho \alpha ́ \mu \mu \alpha \tau \alpha$. Ryto w korze lub naciskano na nią ostrym narzędziem, doprowadzając do jej deformacji ${ }^{3}$. Sporządzano w ten sposób urzędowe zapisy i prywatne. Spisywano listy długów, rachunki handlowe i obliczenia, teksty liturgiczne. Pisano listy, które dotyczyły codziennych zajęć ludzi należących do różnych warstw społecznych, często spraw finansowych. Gramoty powstawały, jak się wydaje, z potrzeby chwili, w określonym celu i w konkretnej sytuacji, w związku z ludzkimi potrzebami, interesami, troskami i radościami, myślami, uczuciami oraz emocjami aktualnymi w danej chwili czy dniu. Są ważnym zjawiskiem. Przyczyniły się m.in. do podjęcia rozważań na temat tego, dlaczego, zwłaszcza w przypadku korespondencji, nie wystarczał przekaz ustny. Uważa się, że wierzono w szczególną siłę słowa pisanego, które uwierzytelniało posłańca i jego misję, a w określonych przypadkach list był po prostu oczekiwaną procedurą. Najpewniej chciano też zapobiec zapomnieniu informacji przez gońca i pomyłce w trakcie przekazywania wiadomości z pamięci (Gippius 2004, s. 204-205; Dekker 2014, s. 18-19; tenże 2018, s. 25-26, 45-46; Shaken i in. 2014, s. 32). Nie jest wykluczone, że funkcje gramot zmieniały się z czasem.

Wciąż nie wiemy, czy korę brzozy wykorzystywano na Rusi jako podłoże pisarskie już w X w. Zdaniem badaczy może na to wskazywać fragment z dzieła Ibn al-Nadīma, ukończonego najpóźniej w 990 r. n.e., którego narracja doprowadzona jest do 377 r. hidżry, tj. 987/988 n.e. (Kalinina [2017-2018] 2019, s. 397, przypis 22; zob. też Žukovskaâ 1959, s. 10-12). Czytamy w nim:

Opowiadał mi pewien (człowiek), na którego szczerości polegam, że jeden $z$ władców góry Kaukaz wysłał go do władcy Rusów; twierdził, że maja oni znaki pisma

${ }^{1}$ Za lekturę tekstu i wszystkie uwagi serdecznie dziękuję prof. Markowi Cetwińskiemu, prof. Władysławowi Duczce, mgr Sylwii Jędrzejewskiej, dr. Rafałowi Rutkowskiemu i dr. Karolowi Żojdziowi oraz anonimowym Recenzentom artykułu.

${ }^{2}$ Odkryto je też w Starej Russie, Pskowie, Torżku, Smoleńsku, Twerze, Moskwie, Riazaniu i Wołogdzie oraz $\mathrm{w}$ Witebsku, Mścisławiu i Dźwinogrodzie. Zob. na stronie http://gramoty.ru (dostęp: 28.10.2019), gdzie baza danych, w tym zdjęcia i podstawowa literatura przedmiotu, oraz w Narodowym korpusie języka rosyjskiego (Национальный корпус русского языка) pod adresem: http://www. ruscorpora.ru/new/search-birchbark.html (dostęp: 28.10.2019). W 2019 r. w Nowogrodzie znaleziono pięć nowych gramot brzozowych, którym nadano numery od 1114 do 1118, zaś w Starej Russie dwie - nr 50 i 51 (zob. http://hist.msu.ru/about/gen.news/53765/; https://nplus1.ru/blog/2019/10/28/ birchbark2019; dostęp: 20.12.2019). Zob. też Gippius, Zaliznâk 2018 i Gippius 2019, gdzie omówienie znalezisk z lat 2017 i 2018.

${ }^{3}$ Dwie gramoty nowogrodzkie - nr 13 i 496, oraz moskiewska nr 3 - zostały napisane atramentem. Pierwszej z nich nie dało się odczytać (zob. Arcihovskij, Ânin 1978, s. 88-90; Zaliznâk 2000b, s. 111-112; Gippius i in. 2011). 
The rolls of birchbark ${ }^{1}$, the white inner layer to be more precise, either from archaeological excavations or construction projects, not only in Veliky Novgorod, inscribed on their very soft inner side and sometimes also on the outside, but rarely on both sides, are an important source for studies of medieval Rus.' ${ }^{2}$ The term "грамота" comes from the Old Rus'ian word for "document" or "letter" (Tihomirov 1953, p. 15; Poppe 1954, p. 370; cf. Lihačëv 1954, p. 326; Zaliznâk 2004, p. 17; Dekker 2018, p. 7), which is in turn a loan word from the Greek $\gamma \rho \alpha \dot{\mu} \mu \alpha \tau \alpha$. The bark was either engraved or pressed with a sharp tool, causing its deformation. ${ }^{3}$ Both official and private records were written down in this way. People would list debts, make calculations and write receipts. They would write down liturgical texts, and compose letters on everyday matters, often financial, occurring in the lives of members of different classes of society. The birchbark texts appear to have reflected a set purpose and specific circumstances linked to people's everyday needs, interests, joys and tribulations, thoughts, emotions of the day or moment. In many instances one can only wonder why, especially in the case of letter writing, oral transmission was deemed unsatisfactory. One theory is that the written word had the power of authenticating the messenger and his mission, and in certain circumstances, the letter was merely expected procedure. Presumably the idea was to prevent issues with the messenger's forgetfulness or imprecise transmission of the memorized message (Gippius 2004, pp. 204-205; Dekker 2014, pp. 18-19; idem 2018, pp. 25-26, 45-46; Shaken et al. 2014, p. 32). It is not to be excluded that the function of the "gramota" changed over time.

Birch bark was introduced as a writing material to Rus', but we still do not know whether this had been accomplished by the $10^{\text {th }} \mathrm{c}$. A fragment from Ibn al-Nadim's work, which the author finished by A.D. 990 at the latest, but in which the narrative ends on Hijri year 377, corresponding to A.D. 987/988, is considered by some researchers as an indication of this (Kalinina [2017-2018] 2019, p. 397, note 22; see also Žukovskaâ 1959, pp. 10-12). It reads:

I was told by one (man), on whose honesty I can depend, that one of the rulers of the mountain of Caucasus sent him to the king of the Rus'; he said that they have

${ }^{1}$ I am greatly indebted to Prof. Marek Cetwiński, Prof. Władysław Duczko, Sylwia Jędrzejewska, PhD Rafał Rutkowski and PhD Karol Żojdź for reading and commenting on a draft of this paper. I would also like to thank the anonymous reviwers of this article.

${ }^{2}$ They have also been found in Stara Russa, Pskov, Torzhok, Smolensk, Tver, Moscow, Ryazan and Vologda, as well as Vitebsk, Mstsislav and Zvenyhorod. See http://gramoty.ru (accessed: 28.10.2019), for database, including photographs and basic references; see also the National Corpus of the Russian Language (Национальный корпус русского языка) at: http://www.ruscorpora.ru/ new/search-birchbark.html (accessed: 28.10.2019). Five new birchbark documents were discovered in Novgorod in 2019 (Nos 1114 to 1118) and two in Stara Russa (Nos 50 and 51) (see http:// hist.msu.ru/about/gen.news/53765/; https://nplus1.ru/blog/2019/10/28/birchbark2019; accessed: 20.12.2019). See also Gippius, Zaliznâk 2018 and Gippius 2019, with a discussion of finds from 2017 and 2018.

${ }^{3}$ Ink was used for writing two of the Novgorod pieces (Nos 13 and 496) and for one from Moscow (No. 3). The first of these could not be read (see Arcihovskij, Ânin 1978, pp. 88-90; Zaliznâk 2000b, pp. 111-112; Gippius et al. 2011). 
wycinane $w$ drewnie. Pokazał mi kawałek białego drewna, na którym były przedstawienia; nie wiem, czy były to słowa, czy oddzielne litery, podobne do tego:

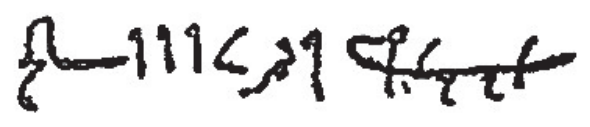

(Kitāb al-Fihrist li-al-Nadīm ${ }^{4}$ )

Znaki mające odwzorowywać pismo widniejące na kawałku białego drewna pokazanego al-Nadīmowi nie zostały odczytane. Ustalono, że w najstarszym rękopisie z końca X - początku XI w., przechowywanym w Chester Beatty Library w Dublinie, i będącym, jak się uważa, kopią autografu, brakuje karty z fragmentem dotyczącym pisma Rusów ${ }^{5}$. Natomiast w manuskrypcie znajdującym się w Bibliotece Köprülü w Stambule, datowanym na początek XIII w., odnośny zapis wygląda trochę inaczej niż powyżej przedstawiony pochodzący z młodszego rękopisu paryskiego (zob. Zajcev, Morozov 2007, s. 113-114). Kwestia ta wymaga dalszych badań (zob. też Franklin 2010, s. 166-168)

Prawie połowę spośród 1201 znanych gramot datuje się na XII w., zaś 35 na XI stulecie. Należą one zatem do najstarszych ruskich przekazów pisanych ${ }^{7}$. Zachowane kodeksy latopisarskie są późniejsze - doprowadzoną do 1234/1235 r. pierwszą część najstarszego rękopisu tzw. synodalnego zawierającego starszą redakcję Pierwszego Latopisu Nowogrodzkiego datuje się bowiem na około 1235 r. lub 2 poł. bądź koniec XIII w. Dotychczasowe ustalenia badaczy wskazują jednak, że w niemałej mierze jest ona kopią wcześniejszego protografu. Druga część rękopisu datowana jest zaś na 1 poł. XIV w. (por. Brzozowska, Petrov 2019, s. VII-IX, tam starsza literatura).

${ }^{4}$ Tłumaczenia tekstów z języka rosyjskiego zamieszczonych w tym artykule wykonał K. Kollinger. Przekład na język rosyjski: „Мне рассказывал один (человек), на правдивость коего я полагаюсь, что один из правителей горы ал-Кабк послал его к правителю ар-русийа; он утверждал, что они имеют письмена, вырезываемые на дереве. Он же показал мне кусок белого дерева, на котором были изображения, не знаю, были ли это слова или отдельные буквы, подобно этому" (za Kalininą [2017-2018] 2019, s. 385).

${ }^{5}$ Zob. https://viewer.cbl.ie/viewer/object/Ar_3315/1/; dostęp: 25.06.2020.

6 Zdaniem Recenzenta artykułu jest możliwe, że „kawałek białego drewna” to faktycznie prawdziwy kawałek drewna - zgodnie ze skandynawską tradycją reprezentowaną przez inskrypcje runiczne wykonane w drewnie, odkryte w 1955 r. w Bergen w Norwegii. Zob. o nich szerzej Liestøl 1964.

${ }^{7}$ Nie trzeba się więc dziwić, że od połowy lat 50., a w większej mierze od przełomu lat 60. i 70. ubiegłego stulecia, Nowogrodzka Ekspedycja Archeologiczna świętowała w dniu 26 lipca, w którym w 1951 r. odkryto pierwszą gramotę, Dzień Gramoty Brzozowej (День Бересты). Od 2011 r. na mocy decyzji Rządu Obwodu stał się on oficjalnym świętem regionalnym w Obwodzie Nowogrodzkim. Zob. https://www.visitnovgorod.ru/afisha/den_beresty.htm?alias=afisha/den_beresty\&ext=htm (dostęp: 28.10.2019). O okolicznościach pierwszego odkrycia zob. Arcihovskij 1953; Ânin 1998, s. 13-49; Horoškevič 2003. Już jednak w 1930 r., na lewym brzegu Wołgi niedaleko wsi Podgornoje (Подгорное, obw. saratowskij, raj. engel’sskij), w grobie złotoordyńskiego skryby znaleziono „książeczkę” spisaną atramentem na korze brzozowej (Malov i in. 2013; Malyšev 2015). 
a writing that is carved in wood. He showed me a piece of white wood, with marks on it; I don't know whether these were words, or separate letters, resembling this:

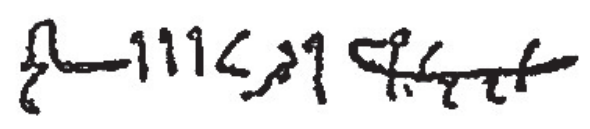

\section{(Kitāb al-Fihrist li-al-Nadīm ${ }^{4}$ )}

The signs imitating writing on the piece of white wood shown to al-Nadim could not be read. The part concerning Rus'ian script appears to have been on a sheet that is missing from the oldest manuscript from the end of the $10^{\text {th }}$ and beginning of the $11^{\text {th }} \mathrm{c}$., now kept in the Chester Beatty Library in Dublin and believed to be a copy of an autograph, ${ }^{5}$ whereas in an early $13^{\text {th }}$ c. manuscript from the Köprülü Library in Istanbul, the relevant part is written in a slightly different way than in the younger Parisian manuscript presented above (see Zajcev, Morozov 2007, pp. 113-114). Further research may yet shed light on the issue (see also Franklin 2010, pp. 166-168). ${ }^{6}$

Nearly half of the 1201 known birchbark documents are dated to the $12^{\text {th }} \mathrm{c}$.; 35 texts are from the $11^{\text {th }} \mathrm{c}$. They are therefore among the earliest written sources from medieval Rus. ${ }^{7}$ The preserved chronicles (letopisi) are later, because the first part of the oldest, so-called synodal manuscript containing the older redaction of the First Novgorod Chronicle, which is brought up to 1234/1235, is dated to about 1235 or the $2^{\text {nd }}$ half or end of the $13^{\text {th }} \mathrm{c}$. However, it has been shown to be to a large extent a copy of an earlier protograph. The second part of the manuscript is dated to the $1^{\text {st }}$ half of the $14^{\text {th }}$ c. (see Brzozowska, Petrov 2019, pp. VII-IX, with earlier references).

${ }^{4}$ Translation from Russian is by the author. For the translation into Russian: "Мне рассказывал один (человек), на правдивость коего я полагаюсь, что один из правителей горы ал-Кабк послал его к правителю ар-русийа; он утверждал, что они имеют письмена, вырезываемые на дереве. Он же показал мне кусок белого дерева, на котором были изображения, не знаю, были ли это слова или отдельные буквы, подобно этому" (after Kalinina [2017-2018] 2019, p. 385).

${ }^{5}$ See https://viewer.cbl.ie/viewer/object/Ar_3315/1/; accessed: 25.06.2020.

${ }^{6}$ It has been raised by one of the reviewers of this text that this "piece of white wood" was indeed wood in keeping with a Scandinavian tradition attested by some runic inscriptions in wood discovered in Norwegian Bergen in 1955. For more on these inscriptions, see Liestøl 1964.

${ }^{7}$ Not surprisingly, since the mid-1950s and more frequently at the turn of the 1960s, the Novgorod Archaeological Expedition has celebrated the Day of the Birchbark Gramota (День Бересты), which falls on July 26, which is the day in 1951 when the first text of this kind was discovered at the site. In 2011, the Province Government set this date as an official regional holiday in the Novgorod District, see https://www.visitnovgorod.ru/afisha/den_beresty.htm?alias=afisha/den_beresty\&ext=htm (accessed: 28.10.2019). On the circumstances of the first discovery, see Arcihovskij 1953; Ânin 1998, pp. 13-49; Horoškevič 2003. In 1930, a "booklet" written in ink on birchbark was discovered in the grave of a scribe of the Golden Horde in the village of Podgornoe (Saratov district) on the left bank of the Volga (Malov et al. 2013; Malyšev 2015). 
Gramoty można wykorzystywać przy rozpatrywaniu wielu tematów (zob. Žukovskaâ 1959, s. 30-85; Čerepnin 1969; Ânin 1998; Ânin ed. 2003) ${ }^{8}$. W niniejszym artykule szerzej omówiona będzie problematyka związana $\mathrm{z}$ analizą korespondencji rytej w korze brzozy, zasygnalizowane zostaną podstawowe zagadnienia źródłoznawcze i przywołana wybrana literatura przedmiotu'

Biorąc na warsztat gramoty brzozowe, należy mieć na uwadze kilka kwestii. Uważa się, że kiedy nie były już potrzebne, wyrzucano je, nieraz drąc na kawałki, a w przypadku listów „tylko" odrywając fragmenty zawierające informacje o adresacie i/lub nadawcy. Często też wdeptywano je w ziemię (Ânin 1998, s. 231, 236-237; Zaliznâk 2004, s. 16; tenże 2006, s. 214). Na jednej z gramot nowogrodzkich, nr 881, wręcz znajdujemy sformułowanie, które interpretuje się jako przypomnienie, że po zapoznaniu się z listem należy go „podrzeć wzdłuż włókien na wiele cienkich pasków-szczapek" ${ }^{\prime 10}$. Nawiązanie do pozbywania się brzozowej korespondencji dostrzegane jest także w tzw. Zapytaniach Kiryka, datowanych na przełom lat 40. i 50. XII w., a zachowanych w kilkudziesięciu rękopisach, z których najstarszy powstał około 1280 r. (zob. Parfenenkov 2012). Kiryk miał zadać biskupowi nowogrodzkiemu Nifontowi m.in. pytanie, czy nie jest grzechem chodzenie nogami po gramotach. Według przekazu jednego z szesnastowiecznych rękopisów otrzymał odpowiedź, iż ,jeśli kto przedrze gramotę i rzuci, ale pozna zapisane słowa, to sprawi, że ona zamilknie"11.

Kontekst archeologiczny znaleziska jest istotny. Inne gramoty i pozostały materiał archeologiczny znaleziony na tym samym poziomie osadniczym, ale też $\mathrm{w}$ danym domostwie i na określonym obszarze, stanowią bowiem integralny zbiór artefaktów. Analiza uwzględniająca te zależności może poszerzyć naszą wiedzę na przykład o właścicielu i mieszkańcach danego domostwa, z którego pochodzi zabytek, ich codziennych zajęciach, lub o rozmaitych okolicznościach posługiwania się zapiskami na zwitkach brzozowych. Możemy lepiej zrozumieć pozostałości materialne, zweryfikować przekazy pisane, spróbować połączyć ze sobą dane otrzymane w wyniku interpretacji materiału archeologicznego i informacji tekstowych. Gramoty są więc szczególnym rodzajem źródeł, będąc zabytkami piśmiennictwa pozyskiwanymi w trakcie wykopalisk archeologicznych (Horošev 1976, s. 94; Burov 1979; Kolčin, Ânin 1982, s. 96-102; zob. też Musin 2003). Datuje się je paleograficznie i lingwistycznie, a niekiedy też historycznie, a jednocześnie archeologicznie, metodą stratygraficzną $\mathrm{z}$ wykorzystaniem danych otrzymanych w wyniku analiz

8 Zob. też w nowszych pracach, np.: Gippius 2017; Temušev 2017; Faradževa 2018; Musin 2019; Rybina 2019; Petrova 2020.

${ }^{9}$ Niedostępne pozostały niestety artykuły Aleksandra Borisowicza Strachowa opublikowane w czasopiśmie „Palaeoslavica” w latach 1993-2001 oraz książka Josa Schaekena (2018).

10 „вдоль волокон на много узеньких полосок-щепочек” (Ânin, Zaliznâk 2004, s. 83).

11 Tłumaczenie z języka staroruskiego K. Kollinger. Tekst staroruski zob. Mil'kov, Simonov 2011, s. 489. Fragment ten wymaga dalszych badań, w tym porównania lekcji we wszystkich znanych rękopisach (por. Simonov 2015, s. 131-132). Warto zauważyć, iż postawiono hipotezę, że wiedzę o gramotach brzozowych posiadał na przełomie XII i XIII w. także Saxo Grammatyk (zob. Słupecki 2013). 
Birchbark manuscripts are relevant to the study of many different topics (see Žukovskaâ 1959, pp. 30-85; Čerepnin 1969; Ânin 1998; Ânin ed. 2003). ${ }^{8}$ A broader discussion will be presented in this article of issues related to the study of correspondence engraved in birch bark, signaling some key aspects of source studies and citing selected literature on the subject. ${ }^{9}$

Researchers studying birchbark manuscripts should be aware of a number of issues. It is believed that when they were no longer needed, they were thrown away, sometimes torn into pieces; in the case of letters, "only" fragments containing information about the addressee and/or sender were torn off. The gramota were also often trampled into the ground (Ânin 1998, pp. 231, 236-237; Zaliznâk 2004, p. 16; idem 2006, p. 214). One of the Novgorod texts (No. 881) contains a remark that is interpreted as a reminder to the reader "to tear it up into many thin strips along the fibers" after reading the letter. ${ }^{10} \mathrm{~A}$ reference to discarding birchbark letters appears also in a work called The Questions of Kiryk, dated to the turn of the 1140s, preserved in the form of several dozen manuscripts copies, the oldest of which comes from about 1280 (see Parfenenkov 2012). Kiryk was said to have asked the Novgorod bishop Niphont whether walking on birchbark documents was a sin. According to one $16^{\text {th }}$-c. manuscript, he was reportedly given the answer that "should one tear a gramota and throw it down, having read it first, one will make it mute". ${ }^{11}$

The archaeological context of the find is important. The other texts and small finds recorded from the same archaeological horizon, as well as the remaining archaeological source material, are an integral set of artifacts. Taking these interdependences into account can give us more data on the owner and the inhabitants of a given household and their everyday activities, or else the different circumstances of using notes written on birchbark rolls. Hence the specificity of birchbark texts as a written source but coming from archaeological excavations. We can better understand the material remains, verify written sources, and attempt to combine data from the interpretation of the archaeological materials and textual evidence (Horošev 1976, p. 94; Burov 1979; Kolčin, Ânin 1982, pp. 96-102; see also Musin 2003). They can be dated on paleographical and linguistic grounds, sometimes also historical ones, but also by the archaeological stratigraphic method using data from dendrochronological analysis of wooden remains, especially the wooden beams used for the successive street surfaces in Novgorod (see, among others, Burov 1997; Noonan, Kovalev 1998, pp. 31-32; Zaliznâk 2000a; Rybina 2019). This dating is

${ }^{8}$ See also newer studies, e.g.: Gippius 2017; Temušev 2017; Faradževa 2018; Musin 2019; Rybina 2019; Petrova 2020.

9 At the time of writing, the author did not have access to articles by Aleksandr Borisovich Strachov in the journal "Palaeoslavica", published in 1993-2001; neither was he able to consult a book written by Jos Schaeken (2018).

10 “вдоль волокон на много узеньких полосок-щепочек” (Ânin, Zaliznâk 2004, p. 83).

11 Translated from Old Rus'ian by the author. For the Old Rus'ian text, see Mil'kov, Simonov 2011, p. 489. The fragment requires further study, including a comparison of the variants from all the known manuscripts ( $c f$. Simonov 2015, pp. 131-132). It has been postulated that the historian Saxo Grammaticus from the turn of the $12^{\text {th }} \mathrm{C}$. also had knowledge of birchbark documents (see Słupecki 2013). 


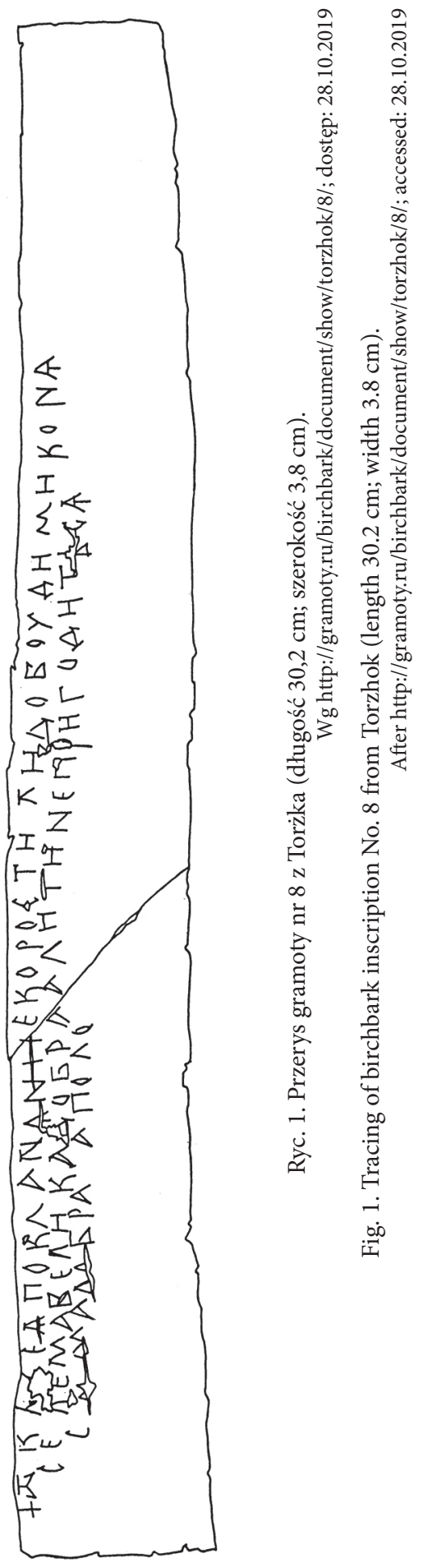




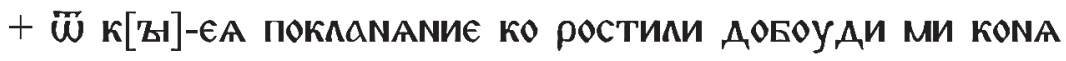

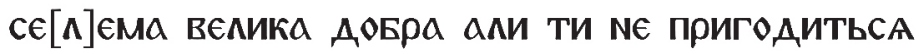 $[\mathrm{c}] \epsilon[\Lambda \epsilon] \mathrm{Ma}, \Lambda$, $о р а$ а поло
}

\author{
Ryc. 2. Podział na słowa tekstu wyrytego na gramocie nr 8 z Torżka (bez skali) \\ Tłumaczenie: Od Kireja ukłon dla Rostili. Dostań (lub: znajdź) dla mnie konia, takiego dużego, dobrego. A jeśli \\ ci się nie uda takiego dobrego, to połowę. \\ Wg http://gramoty.ru/birchbark/document/show/torzhok/8/; dostęp: 28.10.2019 \\ Fig. 2. Text of "gramota" No. 8 from Torzhok divided into words (no scale) \\ Translation: From Kirey greetings for Rostila. Get (or: find) a horse for me, a good, big one. And if you cannot \\ manage a good one, then half. \\ After http://gramoty.ru/birchbark/document/show/torzhok/8/; accessed: 28.10.2019
}

not always convergent. The address formulas are also sometimes a dating element (Gippius 2009). A timeframe indicating when a given gramota was written or lost in the ground is much more likely than an absolute date.

At first, all kinds of natural damage, cracks and spots on the bark surface were wrongly considered as letters and it was difficult to discern between intentional lines forming letters and accidental ones made in the birchbark surface (Tihomirov 1953, pp. 14-15; Kislov 1954). The engraving on some examples seems to be blurred, as if for some reason the surface of the bark had been smoothed (Zaliznâk 1998b, p. 250). Microphotography has proved a useful modern method of research. First, however, a roll of birchbark has to be preserved and conserved (see Kirânov 1954; Povetkin 1996; 2003; Dzendzelûk, L’oda 2009). To be able to read the text one has to know the linguistic traits of the Old Novgorod dialect (see Zaliznâk 2004) ${ }^{12}$ and the graphic, grammatical and spelling rules applied in it. Not the least, one has to be able to divide the text into words and impose punctuation (see Figs 1, 2; example of document No. 8 from Torzhok [Торжок, Tver district] $)^{13}$ and occasionally search for the meaning of terms not known from any other known source texts. Hypothetical identification and reconstruction is performed in the case of fragmentary and torn documents, where particular letters and phrases may be partly illegible or missing (see Zaliznâk 1998a, pp. 425-437; idem 1998b, pp. 249-254; idem 2006, pp. 215-225). It is not rare in the literature to find the same texts republished with new dates, variants, interpretations and translations. ${ }^{14}$ The

${ }^{12}$ Other languages than Old Rus'ian recorded on the Novgorod birchbark manuscripts include Old Karelian (No. 292), Latin (No. 488), Greek (No. 552), and Low German (No. 753). A dictionary of Old Rus'ian and Karelian appears in one of the texts (No. 403). Questions have been raised about the identification of the signs in manuscript No. 11 from Smolensk as Runes (see Pereswetoff-Morath 2017).

13 This document will be analyzed in detail in a new book prepared by the author for print; for an illustration, see Malygin 2011, Fig. 32. There also more on the other birchbark manuscripts from Torzhok.

${ }^{14}$ See in more recent studies: Bogdanov 2015; Gippius 2015; Petruhin 2017; Sičinava 2017; Rybina 2018; also Zaliznâk 1998b, pp. 254-264. See also revisions and commentary to documents published earlier, starting with volume VIII of the series: “Новгородские грамоты на бересте (из раскопок...)"; 12 volumes have appeared to date. 
dendrochronologicznych pozostałości drewnianych, w Nowogrodzie zwłaszcza kłód tworzących kolejne warstwy ulic (zob. m.in. Burov 1997; Noonan, Kovalev 1998, s. 31-32; Zaliznâk 2000a; Rybina 2019). Datowania te nie zawsze są ze sobą zbieżne. Elementem datującym mogą być również formuły adresowe (Gippius 2009). Na ogół możliwe jest wskazanie przedziału czasowego, kiedy dana gramota powstała, czy trafiła do ziemi, a nie chronologii bezwzględnej.

Po odkryciu pierwszych gramot wskazywano na obecność naturalnych uszkodzeń, rys i kropek na powierzchni kory, które błędnie można uznać za linie liter, oraz kresek, które mogły zostać wyryte przypadkowo (Tihomirov 1953, s. 14-15; Kislov 1954). Natrafiono także na egzemplarze z rytami sprawiającymi wrażenie zatartych i z niejasnych powodów wygładzoną korą (Zaliznâk 1998b, s. 250). Czasem w sukurs przychodzą nowsze metody badawcze, jak na przykład mikrofotografia. Najpierw jednak zwitek kory poddaje się restauracji i konserwacji (zob. Kirânov 1954; Povetkin 1996; 2003; Dzendzelûk, Loda 2009). Odczytanie tekstu wymaga też znajomości językowych właściwości dialektu staronowogrodzkiego (zob. Zaliznâk 2004) ${ }^{12}$, ustalenia graficznych, gramatycznych i ortograficznych prawideł zastosowanych $\mathrm{w}$ danym zapisie, a także podzielenia go na słowa i rozłożenia znaków interpunkcyjnych (zob. ryc. 1, 2, gdzie przykład gramoty $\mathrm{nr} 8 \mathrm{z}$ Torżka [Торжок, obw. twerski] $)^{13}$, zaś niekiedy zrozumienia terminów, które nie wystąpiły w znanych tekstach źródłowych. W przypadku fragmentów gramot i urwanych czy częściowo nieczytelnych liter i fraz stosuje się hipotetyczne identyfikacje oraz rekonstrukcje (zob. Zaliznâk 1998a, s. 425-437; tenże 1998b, s. 249-254; tenże 2006, s. 215-225). Nie bez powodu można więc spotkać w literaturze powtórne, nowe i odmienne datowania, lekcje, interpretacje i tłumaczenia ${ }^{14}$. Te ostatnie spełniają dzisiejsze standardy, gdy tłumacz stosuje się do reguł języka docelowego, wtedy też są zrozumiałe dla współczesnych. Każdy przekład to w jakimś stopniu interpretacja tekstu oryginalnego, ale powinno się dążyć do zachowania sensu i stylu wyjściowego oraz przekazywać tę samą informację. Inna rzecz, że trudno jest przewidzieć, jak tłumaczenie zostanie odczytane przez odbiorcę. Nie mogąc natomiast wniknąć w mentalność autora oryginału, często nie jesteśmy w stanie w pełni go zrozumieć, gdyż pisał on w sposób czytelny dla jemu współczesnych. Niedostępny bywa też dzisiaj kontekst sytuacji ${ }^{15}$.

12 Oprócz tekstów napisanych po starorusku z jednej spośród nowogrodzkich gramot odczytano zapis prawdopodobnie w starokarelskim (nr 292), z jednej w łacińskim (nr 488), z jednej w greckim (nr 552), zaś z jednej w dolnoniemieckim (nr 753). Na gramocie nr 403 zapisano starorusko-karelski słowniczek. Kwestionuje się natomiast odkrycie znaków alfabetu runicznego na smoleńskiej gramocie nr 11 (zob. Pereswetoff-Morath 2017).

13 Analizę tej gramoty Czytelnik znajdzie w książce przygotowywanej przez autora do druku, zaś jej zdjęcie w pracy Malygina 2011, ryc. 32. Tam też szerzej o pozostałych gramotach z Torżka.

${ }_{14}$ Por. w nowszych pracach: Bogdanov 2015; Gippius 2015; Petruhin 2017; Sičinava 2017; Rybina 2018; także Zaliznâk 1998b, s. 254-264. Zob. również poprawki i uwagi do wcześniej wydanych gramot, publikowane, począwszy od tomu nr VIII, w kolejnych z serii pt. „Новгородские грамоты на бересте (из раскопок...)”. Dotychczas ukazało się ich dwanaście.

15 Szerzej o rodzajach tłumaczeń i problemach z nimi związanych zob. Majewski 2019 (na przykładzie Biblii) i np. Cronin 2016 oraz Mitâgina ed. 2017. 
latter meet modern standards when the translator uses the rules of the target language and in those cases the texts are understandable to the modern reader. Every translation is to some extent an interpretation of the original language, but one should aim at preserving the meaning and the writing style, while communicating the message. Even if it is impossible to anticipate how it will be read and understood by the person receiving the communication. Without the possibility of entering into the thoughts of the sender, one is at a loss sometimes to understand the meaning of the words, which were intended for the writer's contemporaries. The situational context of these documents is also missing as a rule. ${ }^{15}$

The circumstances in which a letter was written and sent are important. The birchbark document is the outcome of human activity, a record of the moment composed of a set of facts, identifying the individuals involved in a given act of communication. In dealing with a letter, one should take into account the initiator of the act, the sender, the person dictating the text, the "author", the scribe, the forwarder, the "courier", the person receiving the letter, the person reading it, the person listening to someone else reading it aloud and the addressee. The letter structure indicates at times that, possibly according to an etiquette in force, the messenger read the text, although he could also be one of the addressees in the case of records composed of a number of fragments addressed to different persons. In some cases, the documents actually contained instructions for the messenger to remind him what to say to the addressee or what to do, if negotiating or being forced to wait longer for a given matter to be resolved. There is also a birchbark text where a question was written first and the answer added later in the free space left for the purpose. Both parts of this text appear to have been engraved by the same messenger. Hence the discussion of the communicative homogeneity versus heterogeneity of the birchbark texts that can be found in the literature on the subject of the "gramota" (Gippius 2004; Schaeken 2010; 2014; Dekker 2014; 2018, p. 14ff.).

The letter text that the researcher is faced with is encoded, and the archaeological context of a given find needs to be interpreted as well. The written text is laconic as a rule; after all, the addressee was usually informed about the matter the letter was referring to. While the information given by the texts is important, specific and in keeping with the truth, it was not intended for the modern reader; we are reading "someone else's letters" and we cannot know what the author' intentions had been. The addressee was obviously someone who would be able to decipher the message, also possibly the messenger reading the content aloud (Gippius 2004, pp. 184-186; Šelepova 2010, pp. 119-120; Štern 2016, pp. 42-45; Dekker 2018, p. 14). The researcher in this situation is left with hypothetical suggestions. However, unlike the chronicles where the factual information is presented in the interpretation of the chronicler or editor, the birchbark texts present the voice of individual persons, even if sometimes through intermediaries like the scribes and text "authors" (Ânin 1998, pp. 53-54; Gippius 2004, pp. 208-213). It was observed that "every discovery of a birch 'gramota' is not only an important scientific discovery, but also an emotional stress, a poignant

${ }^{15}$ For more on the translations and related issues, see Majewski 2019 (the Bible as an example) and, e.g., Cronin 2016 and Mitâgina ed. 2017. 
Okoliczności, w jakich zaistniała potrzeba spisania tekstu czy wysłania lub otrzymania listu, są ważne. Gramota to produkt działalności człowieka. Chodzi niejako o określenie chwili, na którą złożył się zespół faktów, a także ustalenie osób, które uczestniczyły w danym akcie komunikacji. Gdy mamy do czynienia z listem, należy wziąć pod uwagę: inicjatora aktu, nadawcę, dyktującego tekst, jego „autora”, pisarza, wysyłającego, „kuriera”, odbierającego list, czytającego go, słuchającego odczytywanego pisma i adresata. Struktura tekstu czasem wskazuje, że list, być może zgodnie z etykietą, odczytywał goniec, który mógł też być jednym $\mathrm{z}$ adresatów $\mathrm{w}$ przypadku zapisów składających się $\mathrm{z}$ fragmentów skierowanych do różnych osób. W niektórych wypadkach gramoty zawierały, jak się uważa, instrukcję dla posłańca przypominającą mu, o czym ma powiedzieć adresatowi lub jak się zachować, gdy na przykład będzie zmuszony dłużej zaczekać na wyjaśnienie się danej sprawy bądź prowadzić negocjacje. Wskazano też gramotę, na której napisano zapytanie, a na zostawionym wolnym miejscu odpowiedź na nie. Oba zapisy przypuszczalnie wyrył goniec. W związku z tym w literaturze spotkamy rozważania na temat komunikatywnej jednorodności i niejednorodności listów przekazanych na gramotach (Gippius 2004; Schaeken 2010; 2014; Dekker 2014; 2018, s. 14 n.).

Między uczestnikami aktu komunikacji a badaczem znajduje się tekst, a więc informacje zakodowane, oraz kontekst archeologiczny odkrycia zabytku, również podlegający interpretacji. Przekaz pisany jest na ogół lakoniczny, m.in. dlatego, że adresat znał szczegóły spraw, których dotyczy list. Choć otrzymujemy dostęp do, jak się uważa, tego, co ważne, konkretne i zgodne z prawdą, rzadko możemy uzyskać odpowiedzi na wszystkie pytania, czytamy bowiem nieprzeznaczone dla nas „cudze listy” i nie znamy intencji autora. Tym, który wiedział, jak odkodować przekaz, był adresat gramoty i być może, czasami nietożsamy z nim, odczytujący jej „Zawartość” (Gippius 2004, s. 184-186; Šelepova 2010, s. 119-120; Štern 2016, s. 42-45; Dekker 2018, s. 14). W tej sytuacji uczeni zdani są na stawianie hipotez. $\mathrm{W}$ przeciwieństwie jednak m.in. do latopisów, w których wiedza o tzw. faktach historycznych dochodzi do badaczy w postaci zinterpretowanej przez ich autorów vel redaktorów, w tekstach wyrytych na gramotach przemawiają konkretni ludzie, choć niekiedy za pośrednictwem „autorów” tekstu i pisarzy (Ânin 1998, s. 53-54; Gippius 2004, s. 208-213). Spostrzeżono, że „każde znalezisko gramoty brzozowej to nie tylko istotne odkrycie naukowe, ale też stres emocjonalny, przejmujący akt «ożywienia» dawno zmarłego i zapomnianego przez wszystkich człowieka, po którym, jak się wydawało, nie mogło pozostać żadne wspomnienie, nawet w czasach jego prawnuków i praprawnuków w linii prostej" ${ }^{\prime 6}$. Zadanie badaczy polega na tym, aby go usłyszeć i zrozumieć, poznać i zidentyfikować. Trzeba wszakże pamiętać, że osadzając daną gramotę w czasie i przestrzeni, w mniej lub

16 „Находка любой берестяной грамоты - не только существенное научное открытие, но и эмоциональный стресс, волнующий акт 'оживления’ давно умершего и забытого всеми человека, от которого, казалось, не могло сохраниться никакого воспоминания даже во времена его прямых правнуков и праправнуков" (Ânin 2003, s. 17). 


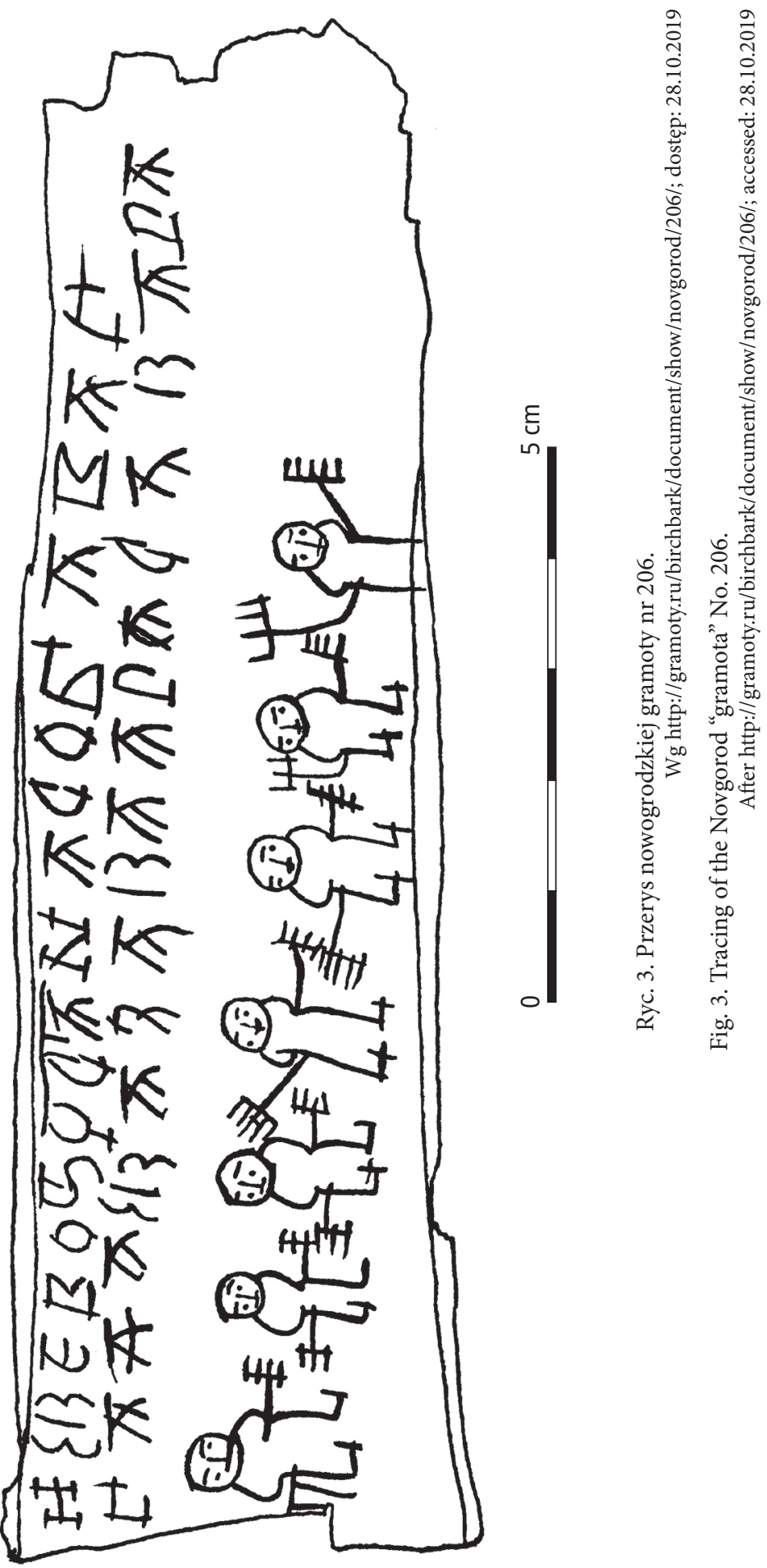


bardziej hipotetycznej przeszłej chwili, ustalając uczestników aktu komunikacji, ich status społeczny i zachodzące między nimi związki i zależności (co umożliwia m.in. analiza doboru formuł adresowych i innych, często gotowych, tradycyjnych wyrażeń i sformułowań; zob. Gippius 2004, s. 186-187; tenże 2009; Šelepova 2010 , s. $119-120)^{17}$, zrozumiawszy przekazywane informacje oraz rozpoznawszy procesy i zjawiska, których dotyczyła gramota, mamy szansę nie tyle odtworzyć minioną rzeczywistość, co stworzyć naszą jej wizję ${ }^{18}$. Z reguły jest ona co najmniej w pewnym stopniu subiektywna, gdyż, o czym często zapominamy, sami jesteśmy również dziejopisarzami (zob. szerzej Cetwiński 2017; także Kollinger 2019).

Zasygnalizowano powyżej, że gramoty można wykorzystywać przy rozpatrywaniu wielu tematów. Znajdziemy wśród nich rozmaite perełki. Najsłynniejsze to nowogrodzkie gramoty o numerach 199-208, 210 i 331. Wiąże się je z chłopcem lub mężczyzną o imieniu Onfim (Онфим), żyjącym w 1 poł. XIII w. Zostawił on po sobie rysunki oraz zapisy będące efektem nauki pisania lub, według innej hipotezy, mające znaczenie magiczne (ryc. 3; zob. Bulanin 1997, s. 154-157; tenże 2010, s. 34-35; Ânin 1998, s. 55-63; Rybina 2018; Stamenova, Danilevskij 2018). Natomiast na gramocie $\mathrm{nr} 17 \mathrm{z}$ Torżka, datowanej na koniec XII w., zapisano fragment Kazania o głębokiej mądrości (Слово о премудрости). Jest to najwcześniejszy znany cytat z tego utworu, tym cenniejszy, że najstarszy rękopis, w którym zachowało się Kazanie, pochodzi z 2 poł. XIII w. (zob. Žolobov 2018). Mająca $55 \mathrm{~cm}$ długości i 8,5 szerokości gramota zaliczana jest do największych spośród odkrytych do tej pory (ryc. 4; zob. Malygin 2011, s. 67 n. i ryc. 41). Jednym z najstarszych znalezisk jest zaś datowana na lata trzydzieste XI w. brzozowa ikona z wyobrażeniami św. Barbary i Chrystusa, odkryta w Nowogrodzie (ryc. 5).

Podjęto badania także nad materialnym nośnikiem informacji, tj. korą brzozową, skupiając jednak uwagę na brzozowych rękopisach (zob. Esipova, Kuklina 2014). Zajęto się również narzędziami do pisania, tzw. pisałami (писало) lub stylusami (łac. stilus). Zidentyfikowano ich 19 typów, z których najstarsze, kościane, datuje się na 2 poł. X - początek XI w., żelazne natomiast od 2 poł. XI w. (zob. Ovčinnikova 2000). Znaleziono je w Europie Wschodniej w kilkudziesięciu ośrodkach, zaś w 2014 r. w Nowogrodzie, w warstwie kulturowej z 2 poł. XII w., odkryto 2 egzemplarze brązowe, pochodzące, jak się uważa, z Europy Zachodniej (zob. Olejnikov 2016). Używano ich nie tylko do pisania na korze, ale też na deseczkach $z$ wydrążonymi polami, które wypełniano woskiem (церы; zob. Rybina 1994). Zauważyć również warto, że nadal nie jest jasne, jakim dokładnie zabiegom poddawano korę brzozy przed jej zapisaniem.

W odniesieniu do polskiego wczesnego średniowiecza mawia się, że istnieją raczej niewielkie szanse odkrycia nowych pisanych przekazów źródłowych i jeste-

17 Ważne znaczenie ma też krzyż, od którego zaczynają się zapisy na części gramot (Poppè 2003, s. 40-41; zob. też ryc. $1 ; 2$ ).

18 Warto przy tym mieć na uwadze, że w tekstach przekazanych na gramotach brzozowych dostrzeżono obecność tzw. listowego czasu przeszłego (zob. Shaken i in. 2014; Dekker 2018, s. 33-34, 115 n.). 

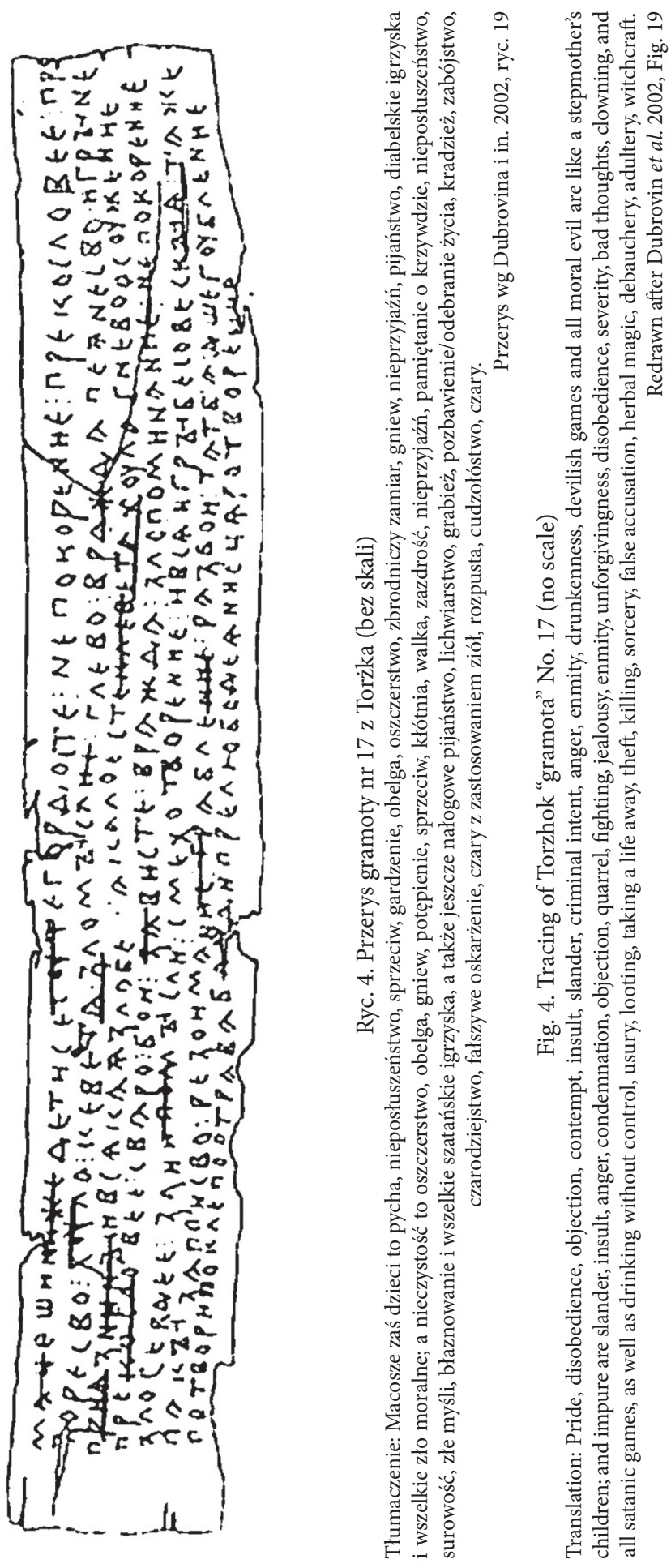

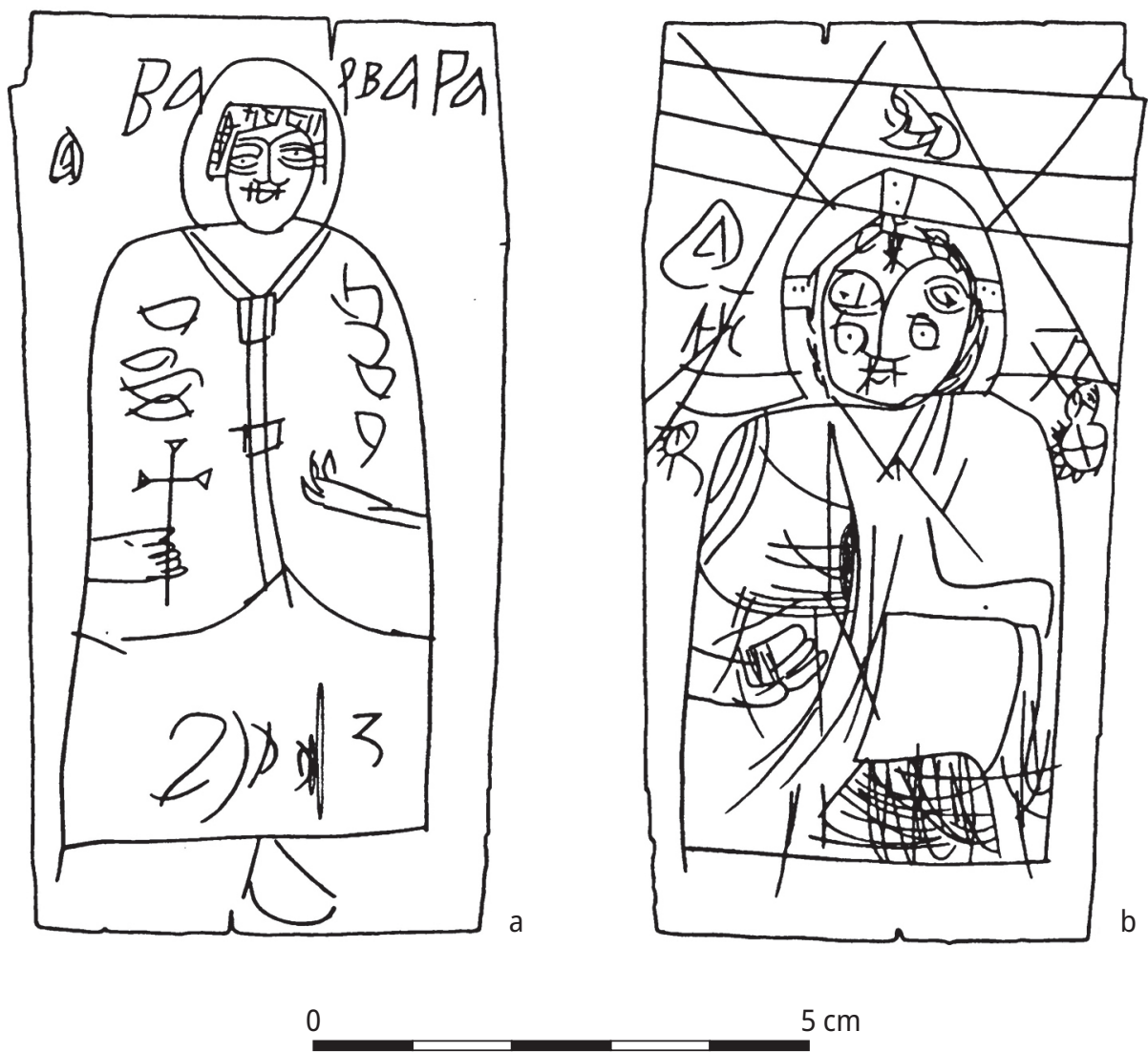

Ryc. 5. Przerys brzozowej ikony z Nowogrodu nr 915i a - św. Barbara; b - Chrystus.

Wg http://gramoty.ru/birchbark/document/show/novgorod/915i/; dostęp: 28.10.2019

Fig. 5. Tracing of a birchbark icon from Novgorod No. 915i a - St. Barbara; b - Christ.

After http://gramoty.ru/birchbark/document/show/novgorod/915i/; accessed: 28.10.2019

śmy zdani na prowadzenie badań na ich niezmiennym zasobie. Uczeni zajmujący się Rusią średniowieczną znajdują się zatem w innej sytuacji. Zbiór gramot brzozowych stale się powiększa, a ich odkrywanie dawno przestało być jedynie domeną archeologów prowadzących wykopaliska w Nowogrodzie Wielkim. Źródła narracyjne, zwłaszcza latopisy, nieraz umożliwiają wgląd „tylko" w autorską vel redaktorską wizję przeszłej rzeczywistości i późniejsze w stosunku do opisywanych wydarzeń wyobrażenia o niej. Dziejopisarze staroruscy na ogół milczą o codziennych problemach „zwykłych” ludzi. Najpewniej nie były dla nich ciekawe, gdyż wszyscy, także oni sami, znali je bardzo dobrze (Ânin 2003, s. 16). 
act of 'revival' of a man long dead and forgotten by all, of whom no memory seemed to have remained, even in the days of his great-grandchildren and great-great-grandchildren in a straight line". ${ }^{16}$ The task of the researcher is to hear and understand, get to know and identify this man. It should be kept in mind, however, that by setting a given birchbark letter in time and space, in a more or less hypothetical moment of the past, and by determining the participants of the act of communication, their social status and the relations and dependencies between them (made possible, among others, by an analysis of address formulas and other, often ready, traditional expressions and phrases; see Gippius 2004, pp. 186-187; idem 2009; Šelepova 2010, pp. 119-120), ${ }^{17}$ having understood the information provided and recognized the processes and phenomena involved, we are recreating not so much a past reality, as our vision of it. ${ }^{18} \mathrm{It}$ is to some degree subjective as a rule, because - although we tend to forget this - we are chroniclers as well (see, more extensively, Cetwiński 2017; also Kollinger 2019).

Birchbark manuscripts can contribute to the study of many different themes. Some of them are true gems. The most famous are Novgorod texts Nos 199-208, 210 and 331. They are associated with a boy or man called Onfim (Онфим), who lived in the $1^{\text {st }}$ half of the $13^{\text {th }} \mathrm{c}$. He has left his drawings as well as what appears to be writing exercises, although some researchers would like to see them as magical texts (Fig. 3; see Bulanin 1997, pp. 154-157; idem 2010, pp. 34-35; Ânin 1998, pp. 55-63; Rybina 2018; Stamenova, Danilevskij 2018). The manuscript No. 17 from Torzhok, from the end of the $12^{\text {th }}$ c., bears a quote from the Sermon of deep wisdom (Слово о премудрости), the earliest known from this work, all the more valuable because the oldest manuscript preserving this work is from the $2^{\text {nd }}$ half of the $13^{\text {th }} \mathrm{c}$. (see Žolobov 2018). The birchbark roll in this case is $55 \mathrm{~cm}$ long and $8.5 \mathrm{~m}$ wide, making it one of the biggest discovered to date (Fig. 4; see Malygin 2011, pp. 67f. and Fig. 41). One of the oldest finds is a birchbark icon depicting St. Barbara and Christ, dating to the 1030s and discovered in Novgorod (Fig. 5).

Investigations have also concerned the material itself, that is, the birchbark, but with emphasis on the birchbark manuscripts (see Esipova, Kuklina 2014). Writing tools have also been considered, such as the писало (in Old Rus'ian) or stylus in Latin; 19 different types have been identified, the oldest from the $2^{\text {nd }}$ half of the $10^{\text {th }}$ and early $11^{\text {th }} \mathrm{c}$. being of bone and from the $2^{\text {nd }}$ half of the $11^{\text {th }} \mathrm{c}$. being of iron (see Ovčinnikova 2000). Writing tools of this kind have been discovered in several centers in eastern Europe and in 2014, two examples made of bronze, believed to have come from Western Europe, were found in Novgorod, in a cultural layer from the $2^{\text {nd }}$ half of the $12^{\text {th }} \mathrm{c}$. (see Olejnikov 2016). They were used to write on birchbark, but also on waxed tablets made of wood

16 “Находка любой берестяной грамоты - не только существенное научное открытие, но и эмоциональный стресс, волнующий акт 'оживления' давно умершего и забытого всеми человека, от которого, казалось, не могло сохраниться никакого воспоминания даже во времена его прямых правнуков и праправнуков" (Ânin 2003, p. 17).

17 The cross, which stands at the beginning of some of these manuscripts, is also of importance (Poppè 2003, pp. 40-41; see also Figs 1; 2).

18 One should keep in mind that texts on birchbark have shown the presence of the so-called epistolary past tense (see Shaken et al. 2014; Dekker 2018, pp. 33-34, 115ff.). 
W tej sytuacji trudno przecenić wartość zapisów na korze brzozy i za wciąż aktualne należy uznać spostrzeżenie sprzed ponad 40 lat, że gramoty brzozowe to w badaniach nad społeczeństwem wczesnośredniowiecznym ,jedyny w swoim rodzaju papierek lakmusowy umożliwiający sprawdzenie trafności [dotychczasowych - K.K.] wniosków historycznych"19.

W literaturze przedmiotu, zwłaszcza starszej, można spotkać termin bieriestołogia (берестология). Nazwy tej użył po raz pierwszy Dmitrij S. Lichaczow, który recenzując pierwsze wydanie książki Walentina Ł. Janina pt. „Я послал тебе бересту...” opublikowane w 1965 r., stwierdził, że „badania nad gramotami brzozowymi stały się specjalną nauką, którą zajmują się setki uczonych"20 ${ }^{20}$ Artiemij W. Arcichowskij natomiast po odkryciu pierwszych gramot przypuszczał, że w przyszłości zostanie dla historyków utworzona nauka pomocnicza podobna do papirologii, dla której proponował określenia bieriestowiedienie (берестоведение) lub flenołogia (фленология; Arcihovskij 1952, s. 57). Dostrzegano także w bieriestołogii naukę filologiczną (Meŝerskij 1995, s. 88) oraz postulowano, aby gramoty były przedmiotem badań nauki działającej na styku paleografii rękopisów i epigrafiki (Žukovskaâ 1963, s. 110). W nowszej literaturze spotkamy natomiast definicję bieriestołogii jako nauki zajmującej się studiami nad zapisami na korze brzozy (Labunec, Šmitt 2016, s. 38).

Po ogłoszeniu przez Lichaczowa faktu powstania nowej „specjalnej” nauki, głos zabrał Walentin Ł. Janin, który konsekwentnie sprzeciwiał się wydzieleniu osobnej nauki pomocniczej historii, żywiąc przekonanie, że nie może przynieść korzyści jednostronne spojrzenie na źródła, jakimi są gramoty. Podkreślał, że będąc przekazami pisanymi, nie przestają być one materiałem archeologicznym i nie można ich wyrywać z kontekstu, w którym zostały odkryte (zob. np. Kolčin, Ânin 1982, s. 97-102). Uważał też, że przedstawiciele poszczególnych dyscyplin humanistycznych nie powinni podążać różnymi drogami, a „konieczność integracji potwierdziła się w trakcie owocnego współdziałania historyków-archeologów i filologów-lingwistów w ramach Nowogrodzkiej Ekspedycji Archeologicznej”"1.

Analizując gramoty, trzeba pamiętać, że są jednocześnie zabytkami piśmiennictwa i materiałem archeologicznym, w związku z czym wymagane jest posłużenie się nie tylko jednym warsztatem badawczym - lingwisty, historyka czy archeologa. Stanowią, jak się wydaje, dobry przykład materiału źródłowego, który pozwala podjąć studia nad wybranym tematem na zasadzie współpracy międzydyscyplinarnej, dającej przedstawicielom różnych dyscyplin szansę wspólnego wyjaśnienia danego zjawiska czy rozwiązania problemu badawczego. Szeroki zakres tematyczny

19 „Берестяные грамоты для современного исследователя раннефеодального общества своеобразная лакмусовая бумага при проверке точности исторических выводов" (Horošev 1976, s. 94).

20 „Изучение берестяных грамот стало особой наукой, в которой принимает участие сотни ученых" (Lihačëv 1966, s. 273).

21 „Необходимость интеграции потвердилась в дальнейшем плодотворным объединением историков-археологов и филологов-лингвистов на базе Новгородской археологической экспедиции" (Ânin [2006] 2007, s. 31). 
(церы; see Rybina 1994). For the present we still do not know what kind of treatment birchbark was subjected to in order to prepare if for its role as writing material.

With regard to the early medieval period in Poland, it is said that the chance for the discovery of new written sources is very slim and that research is constrained by the existing corpora of texts. The situation for researchers of medieval Rus' is different. There is a constant flow of new finds of birchbark documents and the field has long since ceased to be the domain of archaeologists working in Veliky Novgorod. Narrative sources, especially the chronicles, frequently present a view of the past that is the author's or editor's and is later in time to the events described. Old Rus'ian historiographers seldom speak of the everyday life of "ordinary" people. It was of no interest to them, because they, like their readers, were well aware of it (Ânin 2003, p. 16). Thus, the evidence of the birchbark texts cannot be underestimated; a remark made more than 40 years ago has lost nothing of its relevance today: for studies of early medieval society, birchbark texts are still "a kind of litmus paper enabling the accuracy of historical conclusions [to date - K.K.] to be tested" ${ }^{19}$

The term berestology (берестология) is found in the literature on the subject, especially the older publications. The first to use the term was Dmitry Lihačëv, who invented it in his review of the book “Я послал тебе бересту..." by Valentin L. Ânin published in 1965. He wrote there that the study of birchbark manuscripts has become "a special field of science for hundreds of researchers". ${ }^{20}$ Artemij V. Arcihovskij commented on the first discoveries of birchbark texts, saying that soon there would be an ancillary science for historians resembling papyrology and he proposed to call it berestovedenie (берестоведение), or phlenology (фленология; Arcihovskij 1952, p. 57). Berestology was also considered a philological branch of research (Meŝerskij 1995, p. 88) and it was postulated to conduct it at the interface of manuscript paleography and epigraphy (Žukovskaâ 1963, p. 110). In turn, newer literature brings a definition of berestology as a study of writing on birchbark (Labunec, Šmitt 2016, p. 38).

At the time, Ânin consistently objected to Lihačëv's suggestion of establishing a separate branch of science for the study of birchbark documents, expressing the conviction that a one-sided view of the sources would not be beneficial for the field. He emphasized that the manuscripts were at the same time archaeological sources and should not be extracted from the context in which they were discovered (see, e.g., Kolčin, Ânin 1982, pp. 97-102). He also held the opinion that representatives of different fields of the humanities should not go their different ways and that the "necessity of integration was confirmed by the successful cooperation of historians-archaeologists and philologists-linguists within the framework of the Novgorod Archaeological Expedition". ${ }^{21}$

19 “Берестяные грамоты для современного исследователя раннефеодального общества своеобразная лакмусовая бумага при проверке точности исторических выводов” (Horošev 1976, p. 94).

20 “Изучение берестяных грамот стало особой наукой, в которой принимает участие сотни ученых" (Lihačëv 1966, p. 273).

21 “Необходимость интеграции потвердилась в дальнейшем плодотворным объединением историков-археологов и филологов-лингвистов на базе Новгородской археологической экспедиции” (Ânin [2006] 2007, p. 31). 
możliwych badań obrazuje obszerna literatura przedmiotu. Trafnie więc Władimir T. Paszuto blisko 50 lat temu dostrzegł, że bieriestołogia „ma naprawdę bezkresne perspektywy rozwoju"22 . Studia nad gramotami brzozowymi bowiem wciąż nie są zakończone.

${ }^{22}$ „имеет поистине необозримые перспективы развития” (Pašuto 1971, s. 75). 
Studying birchbark texts one should keep in mind that they are both written and material sources, hence requiring different research tools: of a linguist, historian and archaeologist. It would appear that birchbark documents are an excellent source material for interdisciplinary research today, enabling studies of selected themes by researchers representing different disciplines who are tasked with jointly explaining a given issue or phenomenon. The extensive literature on the subject illustrates well the broad range of themes that could be studied. Berestology still continues to have "truly unlimited opportunities for development" as Vladimir T. Pašuto rightly observed close to 50 years ago. ${ }^{22}$ Studies of birchbark manuscripts are still not finished.

22 “имеет поистине необозримые перспективы развития” (Pašuto 1971, p. 75). 


\title{
WYKAZ CYTOWANEJ LITERATURY
}

\author{
BIBLIOGRAPHY OF WORKS CITED
}

\section{ŹRÓDłA / SOURCES}

B rzo z owska Z.A., Petrov I. N. 2019, Latopis nowogrodzki pierwszy starszej redakcji. Unikatowy zabytek piśmiennictwa staroruskiego i jego polski przekład, Series Ceranea, 5, Łódź.

\section{OPRACOWANIA / STUDIES}

Â n i n V. L. 1998, Â poslal tebe berestu..., $3^{\text {rd }}$ editon, Moskva.

Â n i n V. L. 2003, Značenie otkrytiâ berestânyh gramot dlâ izučeniâ otečestvennoj istorii, [in:] Berestânye gramoty. 50 let otkrytiâ i izučeniâ. Materialy meždunarodnoj konferencii Velikij Novgorod, 24-27 sentâbrâ 2001 g., V.L. Ânin ed., Moskva, pp. 15-23.

Â n i n V. L. [ 2006] 2007, «Sovest', blagorodstvo i dostoinstvo otličali Lihačeva» (besedu vela E. Aleksandrovna), „Očen'UM”, 1, K 100-letiû so dnâ roždeniâ D.S. Lihačeva, pp. 30-35.

Ân in V.L. e d. 2003, Berestânye gramoty. 50 let otkrytiâ i izučeniâ. Materialy meždunarodnoj konferencii Velikij Novgorod, 24-27 sentâbrâ 2001 g., Moskva.

Ân in V. L., Z a li z nâk A. A . 2004, Novgorodskie berestânye gramoty № 776-915 (iz raskopok 1997-2000 gg.), [in:] Ânin V.L., Zaliznâk A.A., Gippius A.A., Novgorodskie gramoty na bereste (Iz raskopok 1997-2000 gg.), XI, Moskva, pp. 10-107.

A rcihovskij A.V. 1952, Raskopki 1952 goda v Novgorode, „Vestnik Akademii Nauk SSSR", 22/12, pp. 45-57.

Arcihovskij A.V. 1953, Raskopki 1951 g. v Novgorode, „Sovetskaâ arheologiâ", 18, pp. 342-371.

A r cihovskij A.V., Ân in V.L. 1978, Novgorodskie gramoty na bereste (Iz raskopok 1962-1976 gg.), Moskva.

B o g d a n ov P. V. 2015, Pervaâ tverskaâ berestânaâ gramota. Ocenka datiruîsih dannyh, Sum.: The Tver birchbark manuscripts № 1. Evaluation of data for dating, „Vestnik Tverskogo Gosudarstvennogo Universiteta", Seriâ: Istoriâ, 4, pp. 4-21.

B u l a n i n D. 1997, Der literarische Status der Novgoroder Birkenrinden-Urkunden, „Zeitschrift für Slawistik", 42/2, pp. 146-167.

B ulan in D. M. 2010, Tradicii i novacii v interpretacii russkoj pis'mennoj kul'tury pervyh vekov. Zametki k perevodu knigi S. Franklina «Pis'mennost', obŝestvo i kul'tura v Drevnej Rusi (okolo 950-1300 gg.)», Sankt-Peterburg.

B u r o v V. A. 1979, Zametki o novgorodskih berestânyh gramotah, Sum.: Notes on Novgorod birch-bark charters, „Sovetskaâ arheologiâ”, 1, pp. 218-227.

B u r o v V. A. 1997, O stratigrafičeskoj datirovke novgorodskih berestânyh gramot Nerevskogo raskopa, [in:] Slavânskij srednevekovyj gorod, Trudy VI Meždunarodnogo Kongressa slavânskoj arheologii, 2, V.V. Sedov ed., Moskva, pp. 31-34.

C e t wi ńs k i M. 2017, Drogi i bezdroża dziejopisarstwa, Olsztyn.

C ro n in M. 2016, Przekład w epoce cyfrowej, Kraków. 
Č e r e p n i n L. V. 1969, Novgorodskie berestânye gramoty kak istoričeskij istočnik, Moskva.

D e k k e r S. 2014, Communicative heterogeneity in Novgorod birchbark letters. A case study into the use of imperative subjects, [in:] Dutch Contributions to the Fifteenth International Congress of Slavists, Minsk, August 20-27, 2013, Linguistics, E. Fortuin, P. Houtzagers, J. Kalsbeek, P. Dekker eds., Studies in Slavic and General Linguistics, 40, Amsterdam-New York, pp. 1-23.

D e k k e r P. 2018, Old Russian birchbark letters. A pragmatic approach, Studies in Slavic and General Linguistics, 42, E. Fortuin, P. Houtzagers, J. Kalsbeek eds., Leiden-Boston.

Dubrovin G.E., Malygin P.D., Sarafanova N.A. 2002, Arheologičeskie issledovaniâ $v$ Toržke, „Arheologičeskie otkrytiâ 2001 goda”, pp. 144-145.

D ze nd zel û k L.S., L'o d a L. M. 2009, Rozkrittâ berestânih suvö̈v X i XII stolit', znajdenih na L'vivsinini, Sum.: Birch-bark scrolls X and XII centuries, founded in Lviv, „Visnik Institutu arheologii L'vìv'k'kogo unìversitetu", 4, pp. 46-53.

E s i p ova V.A., Kukli na T. È. 2014, «Zaimočnaâ» kollekciâ. Rukopisi XX vv. na bereste, Tomsk.

F a r a d ž e v a N. N . 2018, Novgorodskie berestânye gramoty kak istočnik dlâ izučeniâ srednevekovogo domostroitel'stva, [in:] «Neskončaemoe leto». Sbornik statej v čest’ Eleny Aleksandrovny Rybinoj, V.K. Singh ed., Moskva-Velikij Novgorod, pp. 232-237.

Franklin S. 2010, Pis'mennost', obŝestvo i kul'tura v Drevnej Rusi: (okolo 950-1300 gg.), Sankt-Peterburg.

Gip pius A.A. 2004, K pragmatike i kommunikativnoj organizacii berestânyh gramot, [in:] Ânin V.L., Zaliznâk A.A., Gippius A.A., Novgorodskie gramoty na bereste (Iz raskopok 1997-2000 gg.), XI, Moskva, pp. 183-232.

G i p pi u s A. A. 2009, Nablûdeniâ nad ètiketnymi formulami berestânyh pisem, [in:] Stereotipy $v$ âzyke, kommunikacii i kul'ture. Sbornik statej, L.L. Fedorova ed., Moskva, pp. 279-300.

G i p p i u s A . A . 2015, Eŝë raz o novgorodskoj berestânoj gramote № 724, „Slověne”, 1, pp. 111127.

G i p p i s A. A. 2017, Berestânaâ gramota № 1072 i denežno-vesovye sistemy srednevekogo Novgoroda, [in:] Rossijskij rubl'. 700 let istorii. Materialy Meždunarodnoj naučnoj konferencii, Velikij Novgorod, 25-27 aprelâ 2016 g., P.G. Gajdukov ed., Velikij Novgorod, pp. 25-36.

G i p p i s A. A. 2019, Berestânye gramoty iz raskopok 2018 g. v Velikom Novgorode i Staroj Russe, „Voprosy âzykoznaniâ”, 4, pp. 47-71.

Gippius A.A., Z aliznâk A. A. 2018, Berestânye gramoty iz raskopok 2017 g. v Velikom Novgorode i Staroj Russe, „Voprosy âzykoznaniâ”, 4, pp. 7-24.

Gippius A.A., Zaliznâk A.A., Koval' V.Û. 2011, Berestânâa gramota iz raskopok v Moskovskom Kremle, [in:] Moskovskij Kreml' XV stoletiâ, 1: Drevnie svâtyni i istoričeskie pamâtniki, S.A. Belâev, I.A. Vorotnikova eds., Moskva, pp. 452-455.

H o r o š e v A.S . 1976, K 25-letiû otkrytiâ berestânyh gramot, „Vestnik Moskovskogo Universiteta”. Seriâ IX: Istoriâ, 31/4, pp. 93-96.

Horoškevi č A.L. 2003, Otkrytie novgorodskih berestânyh gramot v istoriografičeskom kontekste načala 50-h godov XX v., [in:] Berestânye gramoty. 50 let otkrytiâ $i$ izučeniâ. Materialy meždunarodnoj konferencii Velikij Novgorod, 24-27 sentâbrâ 2001 g., V.L. Ânin ed., Moskva, pp. 24-38.

Kal in in a T. M. [2017-2018] 2019, «Fihrist» Ibn an-Nadima (X v.) o pis'me i pis'mennosti nekotoryh vostočno- $i$ zapadnoevropejskih narodov, Sum.: Ibn al-Nadim's Fihrist (the $10^{\text {th }}$ century) in writing and script of some peoples of eastern and western Europe, [in:] Drevnejšie gosudarstva Vostočnoj Evropy. Rannie formy i funkcii pis'ma, T.V. Gimon ed., Moskva, pp. 383-405. 
K i r'ân ov A.V. 1954, Obrabotka berestânyh gramot (Opyt raboty polevoj laboratorii Novgorodskoj arheologičeskoj ékspedicii), „Kratkie soobŝeniâ o dokladah i polevyh issledovaniâh Instituta istorii material'noj kul'tury AN SSSR", 53, pp. 127-130.

K i s lov M. N. 1954, Sposob prorisovki berestânyh gramot i derevânnyh reznyh veŝej, „Kratkie soobŝeniâ o dokladah i polevyh issledovaniâh Instituta istorii material'noj kul'tury AN SSSR", 53, pp. 131-133.

Kolč in B.A., Ân in V.L. 1982, Arheologii Novgoroda 50 let, [in:] Novgorodskij sbornik. 50 let raskopok Novgoroda, B.A. Kolčin, V.L. Ânin eds., Moskva, pp. 3-137.

Kollinge r K. 2019, (rec.) M. Cetwiński, Drogi i bezdroża dziejopisarstwa, Studio AB, Olsztyn 2017, ss. 456, [in:] „Kwartalnik Historii Nauki i Techniki”, 64/1, pp. 167-171.

Labunec N.V., Šmitt O.V.F. 2016, Novgorodskie berestânye gramoty v lingvodidaktičeskoj problematike russkogo âzyka kak inostrannogo, Sum.: Novgorod birchbark documents in linguodidactic issues of teaching Russian as a foreign language, „Vestnik Tûmenskogo gosudarstvennogo universiteta”. Gumanitarnye issledovaniâ. Humanitates, $2 / 4$, pp. 35-44.

L i e st øl A . 1964, Runer frå Bryggen, „Viking. Tidsskrift for norrøn arkeologi”, 27, pp. 5-52.

L i h a č ëv D.S. 1954, (rec.) A. V. Arcihovskij i M. N. Tihomirov. Novgorodskie gramoty na bereste (iz raskopok 1951 g.). Izdatel'stvo Akademii Nauk SSSR, M., 1953, str. 68, [in:] „Sovetskaâ arheologiâ”, 19, pp. 318-327.

L i h a č ë v D.S . 1966, Novaâ nauka - berestologiâ, „Novyj mir”, 42/2, pp. 271-274.

Ma j e w s k i M. 2019, Jak przekłady zmieniaja Biblię. O przekładach i przekładaniu Pisma Świętego raz jeszcze, $2^{\text {nd }}$ edition, Kraków, https://www.academia.edu/5331176/Jak_przekłady_ zmieniają_Biblię._O_tłumaczeniu_Pisma_Świętego_raz_jeszcze (accessed: 23.12.2019).

Malov N.M., Pilipenko P.A., Sergeeva O.V. 2013, Pogrebenie zolotoordynskogo pisca s berestânoj knižečkoj okolo sel Podgornoe - Ternovka, [in:] Arheologiâ Vostočno-Evropejskoj stepi. Mežvuzovskij sbornik naučnyh trudov, 10: Materialy IV Nižnevolžskoj meždunarodnoj arheologičeskoj konferencii (18-21 oktâbrâ 2013 goda), V.A. Lopatin ed., Saratov, pp. 382-396.

Malyg in P. D. 2011, Berestânye gramoty drevnego Toržka (iz raskopok 1985 i 1999-2001 gg.), P.G. Gajdukov ed., Trudy Novotoržskoj Arheologičeskoj Ėkspedicii, I, Tver'.

Maly š e v A. B . 2015, K voprosu ob interpretacii zolotoordynskoj "poèmy» na bereste, najdennoj u sela Podgornoe, [in:] Arheologiâ Vostočno-Evropejskoj stepi. Mežvuzovskij sbornik naučnyh trudov, 11, V.A. Lopatin ed., Saratov, pp. 41-63.

Meŝ e rskij N.A. 1995, Novgorodskie gramoty na bereste kak pamâtniki drevnerusskogo literaturnogo âzyka, [in:] N.A. Meŝerskij, Izbrannye stat'i, Sankt-Peterburg, pp. 88-107.

Mil'kov V. V., S i m o n ov R. A . 2011, Kirik Novgorodec. Učenyj i myslitel', Moskva.

Mitâg in a V.A. ed. 2017, Homo loquens. Voprosy lingvistiki i translâtologii. Sbornik statej, 10, Volgograd.

Mu s i n A.E. 2003, Social'nye aspekty istorii drevnerusskoj Cerkvi po dannym novgorodskih berestânyh gramot, [in:] Berestânye gramoty. 50 let otkrytiâ i izučeniâ. Materialy meždunarodnoj konferencii Velikij Novgorod, 24-27 sentâbrâ 2001 g., V.L. Ânin ed., Moskva, pp. 102-124.

Mus in A. E. 2019, Golovažnâ $i$ voz. K utočnieniû metrologii v srednevekovoj Vostočnoj Evrope, Sum.: Golovazhnya and voz. On the metrology of medieval eastern Europe, „Peterburgskij istoričeskij žurnal”, 3, pp. 58-70.

No on a n T.S., Kovalev R.K. 1998, Čto govorât berestânye gramoty ob èkonomike Kievskoj Rusi, „Russian History”, 25/1-2, pp. 27-49. 
O le j n i k ov O. M. 2016, Novyj tip pis’mennyh prinadležnostej iz Velikogo Novgoroda, Sum.: A new type of writing implements from Novgorod the Great, „Kratkie soobŝeniâ Instituta Arheologii", 242, pp. 191-198.

Ovči n nikova B. B. 2000, Pisala - stilosy drevnego Novgoroda X-XV vv. Svod arheologičeskogo istočnika, [in:] Novgorodskaâ Rus'. Istoričeskoe prostranstvo i kul'turnoe nasledie. Sbornik naučnyh trudov, „Problemy istorii Rossii”, 3, pp. 45-105.

P a rf e n e n k ov V. O. 2012, Traktat XII veka «Voprošanie Kirika». Spiski, redakcii, istočniki, [in:] Kirik Novgorodec i drevnerusskaâ kul'tura, part 2, V.V. Mil'kov ed., Velikij Novgorod, pp. 223-272.

P a š u t o V. T. 1971, Problemy istorii Drevnej Rusi, „Srednie veka”, 34, pp. 72-76.

P e r e s w e t of f - M o r a t h P. 2017, Finns det runor på näverremsan från Smolensk?, Sum.: Are there runes on the birch bark strip from Smolensk?, „Skandinavskaâ filologiâ”, 15/2, pp. 181-192.

P e tr o v a M. I . 2020, Žabij Nos v novgorodskoj berestânoj gramote № 249, Sum.: Cape Zhabij Nos in Novgorod birchbark letter № 249, „Drevnââ Rus'. Voprosy medievistiki”, 1 (79), pp. 7-16.

P e t r u h i n P. V. 2017, K pročteniû novgorodskoj berestânoj gramoty № 490, „Slavânovedenie", 4, pp. 89-92.

P o p p e A. 1954, Zabytki staroruskiej kultury piśmienniczej na korze brzozowej w Nowogrodzie Wielkim, „Kwartalnik Historyczny”, 61/2, pp. 365-374.

P o p p è A. V. 2003, O bračnom kontrakte na Rusi (na osnovanii gramoty na bereste № 9), [in:] Berestânye gramoty. 50 let otkrytiâ $i$ izučeniâ. Materialy meždunarodnoj konferencii Velikij Novgorod, 24-27 sentâbrâ 2001 g., V.L. Ânin ed., Moskva, pp. 39-44.

P ove t k i n V.I. 1996, Opyt vosstanovleniâ novgorodskih berestânyh gramot, Sum.: Reconstruction of birch-bark documents from Novgorod, „Rossijskaâ arheologiâ”, 3, pp. 52-57.

P o v e $\mathrm{t} \mathrm{k}$ i n V. I. 2003, Vosstanovlenie drevnih tekstov. Ot berestânyh gramot $k$ voskovoj Novgorodskoj Psaltyri, [in:] Na perekrëstkah èpoh i tradicij. Sbornik naučnyh trudov, „Problemy istorii Rossii”, 5, pp. 87-95.

Ry b in a E. A. 1994, Cery iz raskopok v Novgorode, [in:] Novgorod i Novgorodskaâ zemlâ. Istoriâ $i$ arheologiâ, 8, V.L. Ânin ed., Novgorod, pp. 129-133.

Ry b i n a E . A . 2018, Berestânaâ gramota № 206 mal'čika Onfima. Istoriâ interpretacii, Sum.: Interpreting the birch bark manuscript no. 205 written by the Novgorod boy Onfim, „Sibirskie istoričeskie issledovaniâ", 4, pp. 130-145.

Ryb i n a E. A . 2019, Ob identifikacii nekotoryh personažej berestânyh gramot №№ 1076 i 1079, Sum.: Identification of some characters of birch bark writings no. 1076 and 1079, „Čelovečeskij kapital", 2 (122), pp. 30-34.

S ch a e ke n J. 2010, Don't shoot the messenger. A pragmaphilological approach to birchbark letter no. 497 from Novgorod, „Russian Linguistics”, 35/1, pp. 1-11.

S ch a e ke n J. 2014, Don't shoot the messenger: part two. Pragmaphilological notes on birchbark letters nos. 497 and 771 from Novgorod and no. 2 from Zvenyhorod, [in:] Dutch Contributions to the Fifteenth International Congress of Slavists, Minsk, August 20-27, 2013, Linguistics, E. Fortuin, P. Houtzagers, J. Kalsbeek, S. Dekker eds., Studies in Slavic and General Linguistics, 40, Amsterdam-New York, pp. 155-166.

S chaeken J. 2018, Voices on Birchbark. Everyday Communication in Medieval Russia, Leiden-Boston.

Shaken J., Fortejn È., D e k ke r P. 2014, Ėpistolârnyj dejksis v novgorodskih berestânyh gramotah, „Voprosy âzykoznaniâ”, 1, pp. 21-38. 
S i č i n a v a D. V. 2017, Pismo k čërtu. Odin maloizvestnyj primer drevnerusskogo plûskvamperfekta, Sum.: The letter to the devil. A little-known instance of the Old Russian pluperfect, „Russkij âzyk v naučnom osveŝenii”, 2 (34), pp. 219-228.

S i m o n ov R. A . 2015, Izučenie tvorčestva Kirika Novgorodca za rubežom, Sum.: The study of creativity Kirik the Novgorodian abroad, „Matematika v vysšem obrazovanii”, 13, pp. 125-142.

Słupecki L.P. 2013, Runic inscriptions from Bergen and birch bark inscriptions from Novgorod. Comparing two ways of writing the vernacular, „Studia Historyczne”, 56/2, pp. 379-385.

St a m e nova A., D a n ilevskij I. 2018, Narisoval na bereste i podpisal v ugolke..., Sum.: Painted on the birch bark and signed in the corner, „Kazus. Individual'noe i unikal'noe v istorii" 13 , pp. 247-256, 346.

Š el e p ova L. I. 2010, Istoričeskaâ rusistika. Antropologičeskij aspekt, „Sibirskij istoričeskij žurnal", 3, pp. 114-121.

Š te r n D. 2016, Pragmafilologiâ, berestânye gramoty i eŝe odno tolkovanie gramoty NGB 19, „Russica romana”, 23, pp. 41-58.

Te m u š e v P. N . 2017, Funkcionirovanie nalogovo-danničeskoj sistemy domongolskoj Rusi po dannym berestânyh gramot, „Drevnââ Rus'. Voprosy medievistiki”, 2 (68), pp. 5-17.

Tihom irov M.N. 1953, Gramoty $i$ nadpisi, [in:] Arcihovskij A.A., Tihomirov M.N., Novgorodskie gramoty na bereste (iz raskopok 1951 g.), Moskva, pp. 12-51.

Z ajcev I.V., Morozov D.A. 2007, Neizvestnyj i bolee rannij variant drevnerusskoj dokirilličeskoj nadpisi Ibn an-Nadima, „Drevnââ Rus'. Voprosy medievistiki”, 2 (28), pp. 112-115.

Z a liznâk A.A. 1998a, Posleslovie lingvista, [in:] Ânin V.L., Â poslal tebe berestu..., $3^{\text {rd }}$ edition, Moskva, pp. 425-449.

Z a li z nâk A . A . 1998b, Problemy izučeniâ berestânyh gramot, [in:] Slavânskoe âzykoznanie. XII Meždunarodnyj s"ezd slavistov. Doklady rossijskoj delegacii, O.N. Trubačev ed., Moskva, pp. 248-266.

Z a liznâk A . A. 2000a, Paleografiâ berestânyh gramot $i$ ih vnestratigrafičeskoe datirovanie, [in:] Ânin V.L., Zaliznâk A.A., Novgorodskie gramoty na bereste (iz raskopok 19901996 gg.), 10, Moskva, pp. 133-429.

Z a li znâk A. A. 2000b, Popravki i zamečaniâ k čteniû ranee opublikovannyh berestânyh gramot, [in:] Ânin V.L., Zaliznâk A.A., Novgorodskie gramoty na bereste (iz raskopok 1990-1996 gg.), 10, Moskva, pp. 82-122.

Z a li z nâk A. A. 2004, Drevnenovgorodskij dialekt, $2^{\text {nd }}$ edition, Moskva.

$\mathrm{Z}$ a li z nâ k A. A. 2006, Berestânye gramoty-bescennyj istočnik svedenij o Drevnej Rusi i ee âzyke, [in:] Lekcii laureatov Demidovskoj premii (1993-2004), Èkaterinburg, pp. 214-237.

Ž ol o b ov O.F. 2018, Slovo-pritča o premudrosti v spiskah XII-XVI vv., [in:] Naučnoe nasledie V. A. Bogorodickogo i sovremennyj vektor issledovanij Kazanskoj lingvističeskoj školy. Trudy i materialy meždunarodnoj konferencii (Kazanskij federal'nyj universitet, 14-17 oktâbrâ 2018 goda, 1, K.R. Galiullin, E.A. Gorobec, Ė.A. Islamova eds., Kazan', pp. 85-90.

Ž u k ov s ka â L.P. 1959, Novgorodskie berestânye gramoty, Moskva.

Žu kovskâa L.P. 1963, Razvitie slavâno-russkoj paleografii (v dorevolûcionnoj Rossii i v SSSR), Moskva. 